\title{
Inventarisasi dan Komposisi Jenis Ektoparasit Ikan Nila (Oreochromis niloticus) Sebagai Biomonitoring Perairan Sungai Tukad Badung, Bali
}

\author{
Alfi Hermawati Waskita Sari a, Rani Ekawaty a \\ a Program Studi Manajemen Sumberdaya Perairan, Fakultas Kelautan dan Perikanan, Universitas Udayana, Bali, Indonesia \\ ${ }^{*}$ Corresponding author. Tel.: +62-361-702-802 \\ Alamat e-mail: alfihermawati@unud.ac.id
}

Diterima (received) 29 Juni 2018; disetujui (accepted) 24 Juli 2018; tersedia secara online (available online) 25 Juli 2018

\begin{abstract}
Environmental stressors which coming from anthropogenic wastes that indirectly enters into the river waters also affect the biota's health in the ecosystem such as the Tilapia Fish (Oreochromis niloticus) which is found in the waters of the Tukad Badung River, Bali. The presence of parasites in fish is also associated with changes of the water quality. The objectives of this study is to provide data and information on the inventory and composition of the parasite species in Tilapia fish (Oreochromis niloticus) as the aquatic health biomonitoring of in the effort of sustainable river ecosystem management. The results of ectoparasit observation of the Tilapia which obtained from five stations in Tukad Badung waters found 6 types of ectoparasites, which are Trichodina sp. Dactylogyrus sp. Gyrodactylus sp., Chilodonella sp., Vorticella sp. and Lernea sp. The composition of the ectoparasite species of nila tilapia fish (Oreochromis niloticus) obtained from all five research stations in Tukad Badung waters by percentage of presence of ectoparasite Trichodina sp. are 70\%, Dactylogyrus sp. 31\%, Gyrodactylus sp. 4\% and Chilodonella sp., Vorticella sp. and Lernea sp. 1\%.
\end{abstract}

Keywords: ectoparasite; compotition; Nile Tilapia;Tukad Badung River

\begin{abstract}
Abstrak
Stressor lingkungan yang berasal dari limbah antropogenik yang masuk kedalam perairan sungai secara tidak langsung juga berdampak terhadap kesehatan biota di ekosistem tersebut seperti halnya Ikan Nila (Oreochromis niloticus) yang juga banyak ditemui di perairan Sungai Tukad Badung, Bali. Keberadaan parasit pada ikan juga berhubungan dengan perubahan kualitas perairan. Tujuan dari penelitian ini adalah memberikan data dan informasi tentang inventarisasi dan komposisi jenis parasit pada ikan Nila (Oreochromis niloticus) sebagai biomonitoring kesehatan perairan berkelanjutan. Hasil pengamatan ektoparasit Ikan Nila yang didapatkan dari lima stasiun di perairan Tukad Badung ditemukan 6 jenis ektoparasit antara lain antara lain Trichodina sp. Dactylogyrus sp. Gyrodactylus sp., Chilodonella sp., Vorticella sp. dan Lernea sp. Komposisi Jenis ektoparasit Ikan Ikan Nila (Oreochromis niloticus) yang didapatkan dari kelima stasiun penelitian di Perairan Tukad Badung diperoleh persentase kehadiran ektoparasit Trichodina sp. sebesar 70\%, Dactylogyrus sp. 31\%, Gyrodactylus sp. $4 \%$ serta Chilodonella sp., Vorticella sp. dan Lernea sp. masing-masing sebesar $1 \%$.
\end{abstract}

Kata Kunci: ektoparasit; komposisi jenis; Ikan Nila; Sungai Tukad Badung

\section{Pendahuluan}

Sungai memiliki penting bagi makhluk hidup, salah satunya sebagai penampung air dari daerah hulu bagian atas dan mengalir hingga ke hilir, oleh karena itu memungkinkan terpengaruh oleh tata guna lahan dan luasnya daerah aliran sungai, sehingga dapat mempengaruhi kualitas air sungai (Odum, 1993). Selain itu juga masuknya limbah domestik dan industri ke dalam sungai seperti pelapisan logam, cat atau tinta warna dan percetakan merupakan stresor lingkungan perairan yang hingga akhirnya dapat menyebabkan dampak 
yang merugikan dan sekaligus berbahaya bagi kehidupan manusia (Wisnu, 1995).

Stresor lingkungan perairan tersebut juga secara langsung berdampak terhadap kehidupan biota yang mendiami ekosistem perairan sungai antara lain seperti adanya kerusakan jaringan dilihat dari gambaran histopatologi seperti halnya yang pernah dilaporkan Kusumadewi dkk. (2015), terkait adanya biokonsentrasi logam berat serta gambaran histopatologi Ikan Mujair pada ekosistem perairan Sungai Tukad Badung, Bali. Selain berdampak langsung terhadap ikan, stressor lingkungan juga berkaitan erat dengan penurunan komposisi jenis parasit ikan sebagai inangnya (Marcogliese, 2005) sebagai adaptasi parasit tersebut untuk merespon perubahan lingkungan perairan (Marcogliese, 2005). Oleh karena itu, informasi awal terkait inventarisasi dan komposisi jenis parasit pada IkanNila (Oreochromis niloticus) di Perairan Sungai Tukad Badung menjadi penting untuk dilakukan sebagai upaya biomonitoring kesehatan ekosistem perairan sungai berkelanjutan.

\section{Metode Penelitian}

\subsection{Waktu dan Lokasi Penelitian}

\subsubsection{Waktu Penelitian}

Penelitian dilaksanakan pada bulan April 2017.

\subsubsection{Lokasi Penelitian}

Sampel ikan Nila (Oreochromis niloticus) sebanyak 25 ekor diambil pada lima stasiun pengambilan sampel di Perairan Sungai Tukad Badung, Bali dengan metode purposive sampling. Selanjutnya, pengamatan ektoparasit dilakukan di

Laboratorium Perikanan, Fakultas Kelautan dan Perikanan, Universitas Udayana.

\subsection{Bahan dan Alat}

Adapun bahan dan alat yang digunakan antara lain sebagai berikut; 25 ekor sampel Ikan Nila (Oreochromis niloticus) yang didapatkan dari lima stasiun pengambilan sampel, akuarium, kantong plastik, aerator, jaring ikan, bubu, seccio set, cawan petri, object glass, cover glass, pipet tetes, kertas tissue, kertas label, penggaris, worksheet dan alat tulis, mikroskop.
2.3 Identifikasi dan Inventarisasi Jenis Ektoparasit Ikan Nila (Oreochromis niloticus)

Pemeriksaan ektoparasit Ikan Nila (Oreochromis niloticus) yang didapatkan dari kelima stasiun di Sungai Tukad Badung, Bali dimulai dengan proses pengerokan (scrapping) bagian luar tubuh ikan tersebut yang meliputi mulut, operkulum, insang dan sirip serta seluruh permukaan tubuh ikan. Hasil scrapping tersebut kemudian diletakkan diatas object glass yang ditetesi sedikit air dan diratakan lalu ditutup dengan coverglass. Pengamatan ektoparasit dilakukan dengan menggunakan mikrokop dengan perbesaran 100x dan 400x. Sebelum dilakukan pencatatan jenis ektoparasit yang ditemukan pada Ikan Nila, dilakukan identifikasi jenis ektoparasit yang ditemukan menurut Kabata (1985).

\subsection{Komposisi Jenis Ektoparasit Ikan Nila (Oreochromis niloticus)}

Komposisi jenis ektoparasit dihitung berdasarkan jumlah dari masing-masing jenis ektoparasit yang ditemukan pada lokasi atau organisme tertentu (Magurran, 2004).

\subsection{Analisa data}

Hasil pengamatan ektoparasit Ikan Nila (Oreochromis niloticus) pada lima stasiun pengambilan sampel kemudian dianalisis secara deskriptif.

\section{Hasil}

3.1 Inventarisasi Jenis Ektoparasit pada Ikan Nila (Oreochromis niloticus) di Perairan Sungai Tukad Badung

Berdasarkan hasil pemeriksaan ektoparasit Ikan Nila (Oreochromis niloticus) yang didapatkan dari setiap stasiun pengambilan sampel ditemukan beberapa jenis ektoparasit yang beberapa diantaranya merupakan filum Cilliophora, Platyhelminthes dan Arthropoda. Beberapa jenis ektoparasit yang ditemukan pada Ikan Nila (Oreochromis niloticus) tersebut antara lain adalah Trichodina sp., Dactylogyrus sp., Gyrodactylus sp., Chilodonella sp., Vorticella sp., Lernaea sp. yang secara lengkap disajikan pada Gambar 1. 


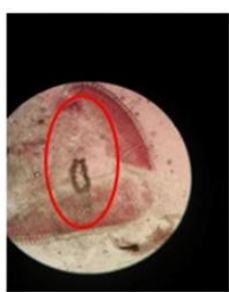

(a)

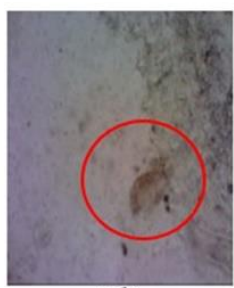

(d)

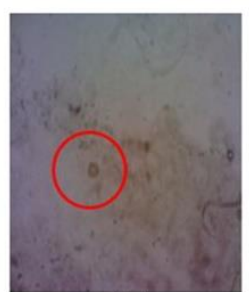

(b)

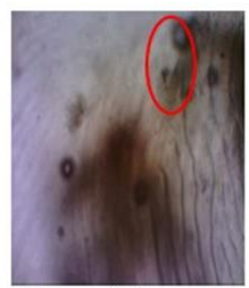

(e)

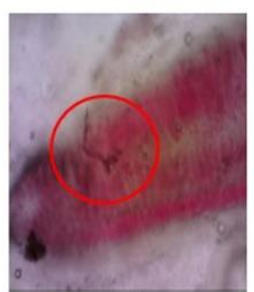

(c)

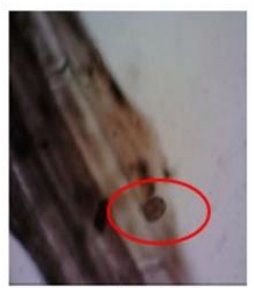

(f)
Gambar 1. Ektoparasit yang ditemukan pada Ikan Nila (Oreochromis niloticus) di Perairan Sungai Tukad Badung, Bali; Dactylogyrus sp. (a), Trichodina sp. (b) Lernaea sp. (c) Gyrodactylus sp. (d) Vorticella sp. (e) Chilodonella sp. (f)

Sedangkan jumlah dan distribusi ektoparasit yang ditemukan pada Ikan Nila pada tiap stasiun Pengambilan sampel di Perairan Sungai Tukad Badung, Bali berturutturut ditunjukkan oleh Tabel 1 dan 2 .

Tabel 1.

Jumlah ektoparasit yang ditemukan pada Ikan Nila (Oreochromis niloticus) tiap stasiun Pengambilan sampel di Perairan Sungai Tukad Badung, Bali.

\begin{tabular}{lccccc}
\hline Jenis Ektoparasit & \multicolumn{5}{c}{ Stasiun } \\
\cline { 2 - 6 } Yang ditemukan & I & II & III & IV & V \\
\hline Trichodina sp. & 19 & 12 & 29 & 91 & 30 \\
Dactylogyrus sp. & 9 & 8 & 7 & 52 & 15 \\
Gyrodactylus sp. & 0 & 0 & 1 & 3 & 6 \\
Chilodonella sp. & 4 & 0 & 0 & 0 & 0 \\
Lernaea sp. & 0 & 0 & 0 & 2 & 1 \\
Vorticella sp. & 0 & 0 & 0 & 0 & 1 \\
$\quad$ Jumlah & 32 & 20 & 37 & 148 & 53 \\
\hline
\end{tabular}

Tabel 2.

Distribusi jenis ektoparasit Ikan Nila (Oreochromis niloticus) tiap stasiun pengambilan sampel di Perairan Sungai Tukad Badung, Bali.

\begin{tabular}{lccccc}
\hline \multirow{2}{*}{ Jenis Ektoparasit } & \multicolumn{5}{c}{ Stasiun } \\
\cline { 2 - 6 } Yang ditemukan & I & II & III & IV & V \\
\hline Trichodina sp. & + & + & + & + & + \\
Dactylogyrus sp. & + & + & + & + & + \\
Gyrodactylus sp. & - & - & + & + & + \\
Chilodonella sp. & + & - & - & - & - \\
Lernaea sp. & - & - & - & + & + \\
Vorticella sp. & - & - & - & - & + \\
\hline
\end{tabular}

3.2 Komposisi Jenis Ektoparasit pada Ikan Nila (Oreochromis niloticus) di Perairan Tukad Badung, Bali.

Kehadiran ektoparasit pada Ikan Nila (Oreochromis niloticus) pada seluruh stasiun pengambilan sampel menunjukkan hasil persentase kehadiran ektoparasit yang paling banyak ditemukan adalah Trichodina sp. sebesar $67 \%$, kemudian cacing parasit Dactylogyrus sp. 31\% dan Gyrodactylus sp. sebesar $4 \%$ serta Chilodonella sp., Vorticella sp. dan Lernea sp. masing-masing sebesar $1 \%$. Persentase komposisi jenis ektoparasit Ikan Nila (Oreochromis niloticus) yang didapatkan di Perairan Sungai Tukad Badung, Bali ditunjukkan Gambar 2.

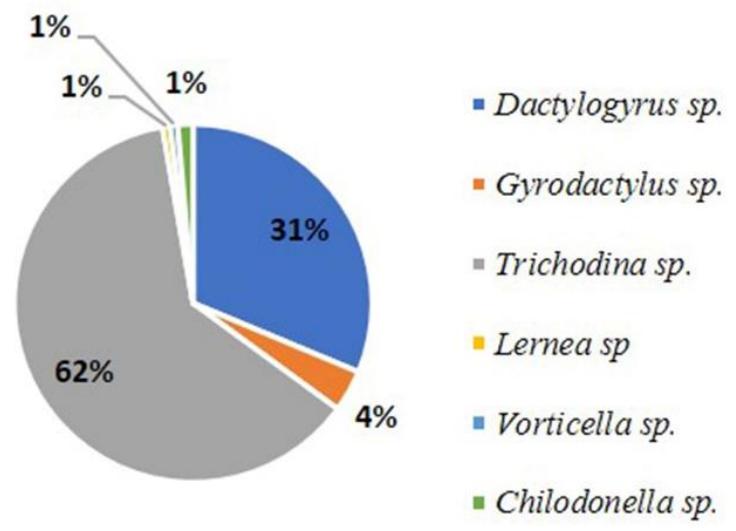

Gambar 2. Komposisi Jenis Ektoparasit pada Ikan Nila (Oreochromis niloticus) di Perairan Sungai Tukad Badung, Bali.

\section{Pembahasan}

Hasil penelitian ini menunjukkan ektoparasit yang paling banyak ditemukan adalah Trichodina sp. Morfologi ektoparasit Trichodina sp. yang ditemukan terdiri dari satu sel yang berbentuk seperti sebuah mangkok terbalik dengan tepian yang melengkung tajam dan runcing seperti pisau (blade) dan membentuk seolah seperti bulan sabit dengan dikelilingi oleh border membran (Kabata, 1985). Ektoparasit Trichodina sp. ditemukan pada ke lima stasiun pengambilan sampel dengan komposisi jenis terbanyak yakni sebesar 62\%. Ghiraldelli et al. (2006) dalam penelitiannya juga menyebutkan bahwa jumlah ectoparasit Trichodina sp. yang ditemukan pada Ikan Nila (Oreochromis niloticus) lebih banyak dibandingkan ektoparasit lainnya. Trichodina sp. merupakan jenis ektoparasit kelas ciliata yang sering ditemukan menyerang ikan air tawar (Anisah dkk., 2017). Selain itu Trichodina sp. memiliki predileksi paling banyak 
ditemukan pada permukaan tubuh ikan (Keremah dan Tariah, 2013) dan juga sirip dan insang ikan (Afrianto dan Liviawaty, 1992).

Ektoparasit yang didapatkan pada Ikan Nila (Oreochromis niloticus) di Perairan Sungai Tukad Badung, Bali juga banyak ditemukan cacing parasitik yang termasuk dalam kelas Trematoda sub kelas monogenea yakni Dactylogyrus sp. Cacing parasit tersebut memiliki ciri-ciri morfologi tubuh memanjang dengan empat buah tonjolan di bagian anterior dan empat bintik mata. Sedangkan pada bagian posterior terdapat ophisthathaptor lengkap dengan 14 marginal hook dan sepasang jangkar (Kabata, 1985). Parasit ini banyak ditemukan dan dilaporkan menyerang ikan pada bagian insang, sebagaimana dalam penelitian Ghiraldelli et al. (2006) yang menyebutkan bahwa cacing monogenea lebih banyak ditemukan pada insang dibanding organ lainnya. Keberadaan ektoparasit tersebut mengakibatkan kerusakan epitelium insang sehingga dapat mempengaruhi pertukaran oksigen hingga akhirnya dapat menyebabkan kematian ikan akibat tidak mampu bernafas (Prayitno dan Sarono, 1996).

Berdasarkan hasil penelitian menunjukkan bahwa komposisi jenis cacing parasit jenis Dactylogyrus sp. sebesar 31\%. Cacing parasit ini ditemukan pada sebagian besar ikan karena tergolong oviparus dimana cacing parasit dewasa akan menghasilkan telur dalam jumlah banyak dan diletakkan di dasar perairan lalu berkembang menjadi larva kemudian bergerak bebas mencari inang definitif (Rahayu dkk., 2013). Gyrodactylus sp. yang ditemukan ditemukan pada ikan Nila yang diperoleh dari stasiun III, IV dan V sebesar 4\% jauh lebih sedikit dibandingkan cacing parasit Dactylogyrus sp. dimungkinkan karena cacing parasit Gyrodactylus sp. merupakan monogenea viviparous dan lebih banyak dilaporkan terutama menyerang benih ikan (Rahayu dkk., 2013).

Ektoparasit lainnya yang ditemukan pada Ikan Nila yang didapatkan pada perairan Sungai Tukad Badung dengan jumlah yang sangat sedikit antara lain adalah Vorticella sp., Chilodonella sp., dan Lernea sp. Vorticella sp., dengan komposisi jenis masingmasing sebesar $1 \%$. Vorticella sp., hanya ditemukan pada stasiun V. Morfologi Vorticella sp. antara lain memiliki zooid yang berbentuk seperti lonceng terbalik, terdiri dari tangkai yang pipih berbentuk seperti bunga yang bersilia serta memiliki makronukleus dan mikronukleus, sel berwarna kekuningan atau kehijauan (Kabata, 1985).
Sedangkan Chilodonella sp. berbentuk bulat oval seperti daun. Chilodonella sp. hanya ditemukan pada stasiun I. Hal ini dimungkinkan Chilodonella sp. dilaporkan lebih banyak ditemukan menyerang benih ikan terutama pada bagian kulit, sirip dan insang (Mulia, 2007). Chilodonella sp. juga memiliki prevalensi yang paling tinggi pada musim hujan (Monir et al., 2015), parasit ini memiliki kemampuan berkembangbiak pada suhu 0,5-20 ${ }^{\circ} \mathrm{C}$ sedangkan pada kondisi yang kurang menguntungkan akan membentuk kista (Purbomartono, 2010).

Selain ektoparasit yang termasuk dalam kelas ciliata, ditemukan pula ektoparasit yang termasuk kelas Lernea sp. crustacea yakni jenis Lernea sp. yang ditemukan hanya pada stasiun IV dan V. memiliki ciri morfologi berbentuk seperti lidi halus yang pada bagian anterior berbentuk jangkar yang digunakan untuk menghujam ke dalam daging inangnya (Kabata, 1985).

\section{Simpulan}

1. Ektoparasit Ikan Nila (Oreochromis niloticus) yang didapatkan dari lima stasiun di perairan Tukad Badung ditemukan 6 jenis ektoparasit antara lain Trichodina sp. Dactylogyrus sp. Gyrodactylus sp., Chilodonella sp., Vorticella sp. dan Lernea sp.

2. Komposisi jenis ektoparasit Ikan Nila (Oreochromis niloticus) yang didapatkan dari lima stasiun penelitian di Perairan Tukad Badung diperoleh persentase kehadiran ektoparasit Trichodina sp. sebesar 70\%, Dactylogyrus sp. 31\%, Gyrodactylus sp. 4\% serta Chilodonella sp., Vorticella sp. dan Lernea sp. masing-masing sebesar $1 \%$.

\section{Saran}

Perlu dilakukan penelitian lanjutan terkait ektoparasit pada jenis ikan lainnya yang mendiami ekosistem Sungai dari hulu hingga hilir sungai Tukad Badung, Bali.

\section{Daftar Pustaka}

Afrianto, I. E., \& Liviawaty, I. E. (1992). Pengendalian Hama dan Penyakit Ikan. Yogyakarta: Penerbit Kanisius.

Anisah, N., Rokhmani, R., \& Riwidiharso, E. (2017). Intensitas dan Variasi Morfometrik Trichodina sp. 
pada Benih Ikan Gurami (Osphronemus gouramy Lacepede) Pendederan I yang Dijual di Pasar Ikan Purwonegoro Kabupaten Banjarnegara. Majalah Ilmiah Biologi BIOSFERA: A Scientific Journal, 33(3), 134-141.

Ghiraldelli, L., Martins, M. L., Jerónimo, G. T., Yamashita, M. M., \& Adamante, W. B. (2006). Ectoparasites communities from Oreochromis niloticus cultivated in the State of Santa Catarina, Brazil. Journal of Fisheries and Aquatic Science, 1(2), 181-190.

Kabata, Z. (1985). Parasites and diseases of fish cultured in the tropics. British Columbia, Canada: Pacific Biological Station Nanaimo.

Keremah, R. I., \& Inko-Tariah, M. B. (2013). Comparative study of ectoparasites on Nile tilapia (Oreochromis niloticus) cultured under integrated and unintegrated pond systems. African Journal of Biotechnology, 12(19), 2711-2714.

Kusumadewi, M. R., Suyasa, I. W. B., \& Berata, I. K. (2015). Tingkat biokonsentrasi logam berat dan gambaran histopatologi ikan mujair (Oreochromis mossambicus) yang hidup di perairan tukad badung kota Denpasar. ECOTROPHIC: Jurnal Ilmu Lingkungan (Journal of Environmental Science), 9(1), 25-34.

Magurran, A.E. (2004). Measuring biological diversity, 1 ed. Oxvord, UK: Blackwell Publishers.

Marcogliese, D. J. (2005). Parasites of the superorganism: are they indicators of ecosystem health?. International journal for parasitology, 35(7), 705-716.
Mulia, D. S. (2007). Tingkat Infeksi Ektoparasit Protozoa pada Benih Ikan Nila (Oreochromis niloticus) di Balai Benih Ikan (BBI) Pandak dan di Balai Benih Ikan (BBI) Sidabowa Kabupaten Banyumas. Sain Akuatik, 10(1), 111.

Monir, S., Bagum, N., Rahman, S., Ashaf-Ud-Doulah. M., Bhadra, A., \& Borty, S.C (2015). Parasitic diseases and estimation of loss due to infestation of parasites in Indian major carp culture ponds in Bangladesh. International Journal Fisheries and Aquatic Studies, 2(5), 118-122.

Odum, E.P. (1993). Dasar-dasar Ekologi. Terjemahan Tjahjono Samingan. (Edisi Ketiga). Yogyakarta: Gadjah Mada University Press.

.Prayitno, S. B., \& Sarono, A. (1996). Deskripsi Hama dan Penyakit pada Ikan Mas (Cyprinus carpio) dan Udang. Pusat karantina Pertanian dan Fakultas Perikanan dan Ilmu Kelautan Universitas Diponegoro. Jakarta.

Purbomartono, C. (2010). Identify of helminth and crustacean ectoparasites on Puntius javanicus fry at local hatchery center Sidabowa and Kutasari. Sains Akuatik, 10(2), 134-140.

Rahayu, F. D., Ekastuti, D. R., \& Tiuria, R. (2013). Infestasi cacing parasitik pada insang ikan Mujair (Oreochromis mossambicus). Acta VETERINARIA Indonesiana, 1(1), 8-14.

Wisnu, A. W. (1995). Dampak Pencemaran Lingkungan, cetakan pertama. Jakarta: Andi Offset.

(C) 2018 by the authors; licensee Udayana University, Indonesia. This article is an open access article distributed under the terms and conditions of the Creative Commons Attribution license (http://creativecommons.org/licenses/by/3.0/). 